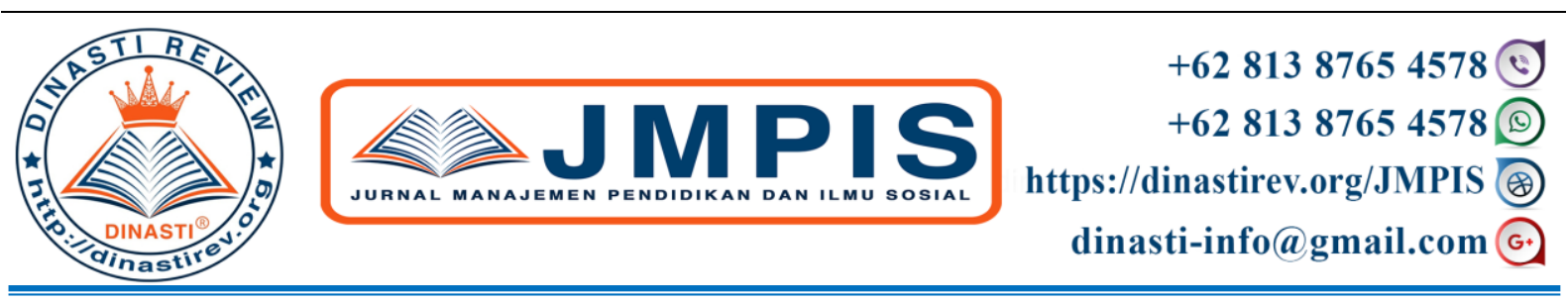

\title{
ANALISIS REAKSI KINERJA KEUANGAN PERUSAHAAN PADA SEKTOR PROPERTI DAN REAL ESTATE YANG TERDAFTAR DI BURSA EFEK INDONESIA
}

Siti Parida ${ }^{1)}$

1) UPBJJ-UT Pangkalpinang

\begin{tabular}{|c|l|}
\hline $\begin{array}{c}\text { ARTICLE INFORMATION } \\
\text { Received: 27 April } 2020 \\
\text { Revised: } 9 \text { Mei } 2020 \\
\text { Issued: } 17 \text { Mei } 2020\end{array}$ & $\begin{array}{l}\text { Abstrak: Penelitian ini bertujuan untuk mengetahui } \\
\text { analisis kinerja keuangan perusahaan properti dan real } \\
\text { estate yang terdaftar di Bursa Efek Indonesia (BEI) } \\
\text { yang diukur melalui rasio likuiditas, rasio solvabilitas } \\
\text { dan rasio profitabilitas. Metode yang digunakan adalah } \\
\text { metode purpsive sampling dimana dari 46 perusahaan } \\
\text { yang ada dipapan utama hanya 5 perusahaan yang } \\
\text { digunakan dalam penelitian berdasarkan jumlah saham } \\
\text { beredar terbanyak yang ada di papan utama. Metode } \\
\text { analisis yang digunakan adalah analisis rasio. Hasil } \\
\text { Eenelitian menunjukkan bahwa perusahaan dengan } \\
\text { kinerja keuangan baik yang ditinjau dari rasio } \\
\text { karida.rasyid @gmail.com } \\
\text { likuiditas adalah Pakuwon Jati Tbk (PWON), } \\
\text { sedangkan yang kurang baik adalah Puradelta Lestari } \\
\text { Tbk (DMAS). Selanjutnya penilaian kinerja keuangan } \\
\text { perusahaan yang baik ditinjau dari rasio solvabilitas } \\
\text { adalah Puradeltas Lestari Tbk (DMAS) dan kinerja } \\
\text { kurang baik adalah Pakuwon Jati Tbk (PWON). } \\
\text { Penilaian kinerja yang ditinjau dari rasio profitabilitas } \\
\text { memberikan hasil kinerja perusahaan yang baik adalah } \\
\text { Puradelta Lestari Tbk (DMAS) dan yang kurang baik } \\
\text { adalah Lippo Karawaci Tbk (LPKR). } \\
\text { Kata Kunci: Rasio Likuiditas, Rasio Solvabilitas dan } \\
\text { Rasio Profitabilitas. }\end{array}$ \\
\hline
\end{tabular}

\section{PENDAHULUAN}

Kemajuan perekonomian disuatu negara dapat ditinjau dari perkembangan bisnis yang terdapat di negara tersebut, salah satunya adalah negara Indonesia yang merupakan negara berkembang di kawasan Asia serta memiliki keunggulan perekonomian di bidang industri dan mempunyai bermacam-macam sektor industri baik industri berskala kecil maupun berskala besar. Salah satunya sektor terpenting di suatu negara adalah sektor Properti dan Real Estate dimana hal ini bisa dijadikan indikator kesehatan suatu negara (Hasanah, et al, 2017).

Properti adalah harta yang berbentuk tanah dan gedung beserta sarana yang menggambarkan elemen yang tidak tepisahkan pada tanah dan gedung sedangkan real estate merupakan properti yang terdiri dari tanah dan bangunan diatasnya, bersama dengan sumber 
daya seperti tanaman, mineral, atau air, benda yang tidakbergerak lainnya di alam ini serta dinyatakan sebagai suatu aset nyata. Perkembangan industri properti dan real estate tentu saja akan meningkat setiap tahunnya itu karena kebutuhan akan papan (tempat tinggal) merupakan kebutuhan pokok manusia yang diikuti dengan pertumbuhan jumlah penduduk (Febrianty dan Wulandari, 2017). Selain itu pemerintah memprioritaskan masyarakat yang berpenghasilan rendah untuk mendapatkan tempat tinggal. Hal ini sesuai dengan UUD 1945 pasal $28(\mathrm{H})$ " Setiap orang berhak hidup sejahtera lahir dan batin, bertempat tinggal, dan mendapatkan lingkungan hidup yang baik dan sehat serta berhak memperoleh pelayanan. Kondisi ini dapat dilihat dari paket kebijakan yang dikeluarkan pemerintah Indonesia pada bulan September 2015 dimana salah satu kebijakannya adalah mendorong investasi di sektor properti merupakan salah satu cara untuk mengefektifkan kemajuan bangunan tempat tinggal untuk masyarakat yang berpenghasilan rendah (CNN Indonesia Ekonomi, 2015).

Kegiatan perekonomian di suatu negara tidak bisa lepas dari investasi, dimana sarana untuk melakukan investasi adalah di pasar modal. Pasar modal dapat dijadikan sebuah indikator kemajuan perekonomian suatu negara. Pasar modal merupakan media yang sangat efektif untuk dapat menyalurkan dan menginvestasikan dana yang berdampak produktif dan menguntungkan investor. Perusahaan yang membutuhkan dana dapat menjual surat berharga di pasar modal. Surat berharga yang biasa dijual dipasar modal adalah saham. Saham adalah satuan nilai atau pembukuan dalam berbagai instrumen finansial yang mengacu pada bagian kepemilikan sebuah perusahaan.

Penelitian ini mengambil sampel perusahaan dengan perusahaan yang jumlah saham yang beredar terbanyak di papan utama dimana dengan penyebaran saham yang bayak berarti banyak investor yang tertarik terhadap perusahaan tersebut. Perusahaan yanga ada dipapan utama adalah pencatatan perusahaan terbuka yang telah memiliki kriteria tertentu seperti perusahaan tercatat telah beroperasi selama 3 tahun, jumlah aktiva berwujud bersih Rp. 100 miliar dan jumlah pemegang saham lebih dari 1.000 pihak. Berikut daftar perusahaan yang menjadi sampel dalam penelitian:

\section{Tabel 1.1 Daftar Perusahaan Properti dan Real Estate dengan Jumlah Saham yang Beredar Terbanyak dalam Papan Utama yang Terdaftar di BEI}

\begin{tabular}{|l|l|r|r|}
\hline No & \multicolumn{1}{|c|}{ Nama } & Jumlah Saham Yang Beredar & \multicolumn{1}{|c|}{ Harga Saham } \\
\hline 1 & LPKR & $\mathbf{7 0 . 8 9 8 . 0 1 8 . 3 6 9}$ & 254 \\
\hline 2 & PPRO & 61.675 .671 .883 & 110 \\
\hline 3 & BKSL & 55.258 .664 .979 & 121 \\
\hline 4 & DMAS & 48.198 .111 .100 & 296 \\
\hline 5 & PWON & 49.159 .602 .400 & 675 \\
\hline
\end{tabular}

Sumber: Bursa Efek Indonesia (BEI), 2019

Berdasarkan Tabel 1.1 tersebut menjelaskan saham industri properti dan real estate di Indonesia semakin banyak peminatnya sehingga hal tersebut menimbulkan persaingan yang semakin ketat antar perusahaan. Persaingan yang semakin ketat adalah cara yang dapat mendorong perusahaan untuk memperbaiki kinerja keuangan (Nafilah,et al, 2019).

Husnan dan Pujiastitu (2007) menyatakan kinerja keuaangan adalah alat menilai prestasi dan kondisi keuangan perusahaan, dimana seorang analisis keuangan memerlukan ukuran terrtentu. Kinerja keuangan sangat dibutuhkan oleh perusahaan untuk mengetahui dan mengevaluasi sampai mana tingkat keberhasilan perusahaan berdasarkan aktivitas keuangan yang telah dilaksanakan (Prima, et al, 2019). Dalam menilai kinerja keuangan suatu 
perusahaan makadigunakan tolak ukur dan tolak ukur yang sering digunakan dalah rasio (Debby Hamdani, 2018). Analisis rasio keuangan adalah future oriented atau berorientasi pada masa depan artinya bahwa dengan analisis rasio keuangan digunakan sebagai alat untuk meramalkan keadaaan keuangan serta hasil usaha dimasa yang akan datang (Munawir, 2010).

Penilaian kinerja keuangan merupakan salah satu cara yang dapat dilakukan oleh pihak manajemen agar dapat mencapai tujuan yang ditetapkan serta ,mencermati kondisi dan kinerja keuangan perusahaan. Kinerja keuangan adalah suatu analisis yang dilakukan untuk menilai sejauh mana perusahaan telah melaksanakan dengan menggunakan aturan-aturan pelaksanaan keuangan secara baik dan benar (Fahmi, 2016). Untuk mengetahui dengan tepat bagaimana kinerja keuangan perusahaan maka diperlukan analisis rasioyang tepat yaitu dengan membandingkan angka-angka yang ada didalam pos-pos laporan keuangan. Analisis rasio yang digunakan dalam penelitian ini adalah analisis rasio likuiditas, rasio solvabilitas dan rasio profitabilitas.

Berdasarkan uraian tersebut maka peneliti merasa perlu melakukan penelitian mengenai kinerja keuangan perusahaan sektor properti dan real estate dengan jumlah saham beredar terbanyak dan dalam papan utama yang terdaftar pada BEI( Bursa Efek Indonesia) Tahun 2016 sampai dengan 2018 dengan judul Analisis Reaksi Kinerja Keuangan Perusahaan pada Sektor Properti dan Real Estate yang terdaftar di Bursa Efek Indonesia

\section{KAJIAN PUSTAKA \\ Kinerja Keuangan}

Kinerja keuangan adalah suatu analisis yang dilakukan untuk menilai sejauh mana perusahaan telah melaksanakan dengan menggunakan aturan-aturan pelaksanaan keuangan secara baik dan benar (Fahmi, 2016). Untuk mengetahui dengan tepat bagaimana kinerja keuangan perusahaan maka diperlukan analisis rasioyang tepat yaitu dengan membandingkan angka-angka yang ada didalam pos-pos laporan keuangan. Analisis rasio yang digunakan dalam penelitian ini adalah analisis rasio likuiditas, rasio solvabilitas dan rasio profitabilitas.

\section{Rasio Likuiditas}

Rasio likuiditas merupakan rasio yang meunjukkan kemampuan perusahaan dalam memenuhi kewajiban jangka pendeknya secara tepat waktu (Fahmi, 2016). Likuiditas adalah kemampuan untuk mengubah aset menjadi uang tunai dengan lebih cepat dan mudah. Perusahaan dapat dikatakan dala keadaan likuid apabila mampu melakukan pemenuhan terhadap kewajibannya secara tepat waktu, sehingga utang yang dimiliki perusahaan lebih kecil dibandingkan aktiva yang dimiliki perusahaan. Rasio likuiditas yang digunakan dalam penelitian ini dalah rasio lancar, dan rasio cepat.

\section{Rasio Solvabilitas}

Rasio solvabilitas adalah rasio yang digunakan untuk mengukur sejauh mana aktiva perusahaan dibiayai oleh utang (Kasmir, 2014). Penggunaan utang yang terlalu tinggi dapat membahayakan perusahaan karena perusahaan akan masuk ke dalam kategori extreme leverage (utang ekstrim) yaitu perusahaan terjebak dalam tingkat utang yang tinggi dan sulit melepaskan beban utang tersebut. Dengan demikian perusahaan harus meyeimbangkan berapa utang yang layak diambil dan darimana sumber-sumber yang dapat dipakai untuk membayar utang (Fahmi, 2016).

\section{Rasio Profitabilitas}

Rasio profitabilitas merupakan rasio untuk menilai kemampuan perusahaan dalam mencari keuntungan (Kasmir, 2016). Perusahaan dapat dikatakan profit apabila perusahaan mampu dalam menghasilkan laba bersih dari aktivitas yang dilakukan pada periode 
akuntansi. Profitabilitas perusahaan adalah gambaran yang mengukur seberapa besar kemampuan perusahaan untuk menghasilkan laba dari kegiatan operasional yang telah dilaksanakan untuk menjamin kelangsungan perusahaan dimasa yang akan datang. Investor dan perusahaan biasanya sering memperhatikan perkembangan dari rasio profitabilitas untuk membuat keputusan investasi dan kebijakan perusahaan. Rasio profitabilitan yang digunakan dalam penelitian ini adalah ROA, ROE dan NPM.

\section{Kerangka Pemikiran}

Kerangka penelitian dalam penelitian ini adalah sebagai berikut:

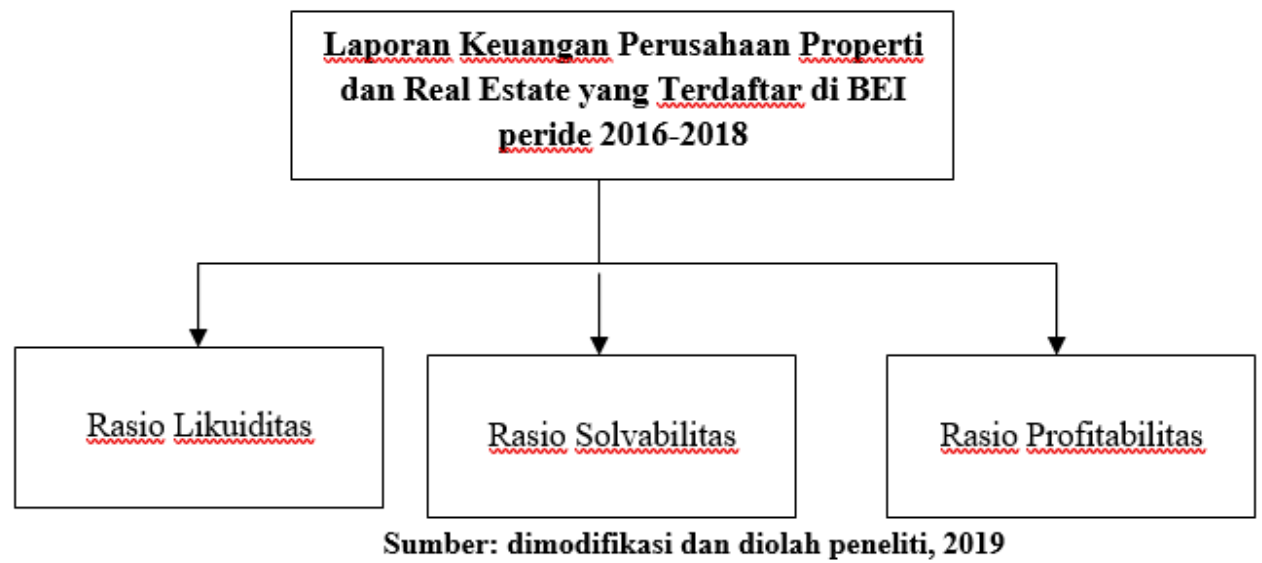

\section{METODE PENELITIAN}

Jenis penelitian yang digunakan dalam penelitian adalah dengan metode kuantitatif deskriptif. Populasi dalam penelitian adalah perusahaan prperti dan real estate yang terdaftar di BEI Tahun 2016-2018 dengan jumlah perusahaan sebanyak 46 perusahaan di papan utama. Teknik pengambilan sampel dalam penelitian ini adalah purposive sampling dimana penentuan sampel dengan kriteria tertentu. Sampel yang digunakan adalah perusahaan properti dan real estate yang terdaftar di BEI yang berada di papan utama dengan jumlah saham yang beredar terbanyak sebanyak 5 perusahaan periode 2016-2018. Teknik analisis data yang digunakan adalah analisi rasio seperti rasio likuiditas( rasio lancar dan rasio cepat), rasio solvabilitas (DER dan DAR) dan rasio profitabilitas ( ROA,ROE, dan NPM).

\section{Rasio Profitabilitas}

\section{Rasio Lancar}

Rasio yang menunjukkan kemampuan perusahaan dalam memenuhi kebutuhan utang ketika jatuh tempo. Rumus yang digunakan adalah sebagai berikut:

Rasio Lancar $=\frac{\text { Altiva Lancar }}{\text { Utang Lancar }} \times 100 \%$

\section{Rasio Cepat}

Rasio yang menunjukkan ukuran solvensi jangka pendek yang lebih teliti dibandingkan rasio lancar karena rasio ini mengeliminasi persediaan karena dianggap aktiva lancar yang sedikit tidak likuid dan kemungkinan menjadi sumber kerugian. Rumus yang digunakan adalah sebagai berikut:

Rasio Lancar $=\frac{\text { Aktiva Lancar-Persediagn }}{\text { Utang Lancar }} \times 100 \%$

\section{Rasio Solvabilitas}

\section{DER}


DER adalah Ukuran yang dipakai dalam menganalisis laporan keuangan untuk memperlihatkan besarnya jaminan yang tersedia untuk kreditor. Adapun rumus DER adalah: DER $=\frac{\text { Total Utang }}{\text { Total Ekuitas }} \times 100 \%$

\section{DAR}

DAR adalah rasio yang melihat perbandingan utang perusahaan yaitu diperoleh dari perbandingan total utang dibagi dengan total aset. Adapun rumus DaR adalah:

$\mathrm{DAR}=\frac{\text { Total Utang }}{\text { Total Aktiva }} \times 100 \%$

\section{Rasio Profitabilitas}

\section{ROA}

ROA merupakan ukuran kemampuan perusahaan dalam menghasilkan laba dengan semua aktiva yang dimiliki oleh perusahaan. Rasio ini dirumuskan sebagai berikut:

ROA $=\frac{\text { Laba Bersih }}{\text { Total Aktiva }} \times 100 \%$

\section{ROE}

ROE menunjukkan kemampuan perusahaan dalam menghasilkan keuntungan dengan modal sendiri yang dimiliki. Rasio ini dirumuskan sebagai berikut:

$\mathrm{ROE}=\frac{\text { Laba Bersih }}{\text { Total Ekuitas }} \times 100 \%$

\section{NPM}

NPM adalah rasio yang juga disebut sebagai rasio laba bersih terhadap penjualan/pendapatan. Rasio ini dirumuskan sebagai berikut:

$\mathrm{NPM}=\frac{\text { Laba Bersih }}{\text { Penjualan/pendapatan Bersih }} \times 100 \%$

\section{HASIL DAN PEMBAHASAN}

Hasil yang diperoleh dalam penelitian dengan sampel 5 perusahaan properti dan real estate yang di ukur menggunakan rasio likuiditas, rasio solvabilitas dan rasio profitabilitas adalah sebagai berikut:

\section{KESIMPULAN DAN SARAN}

Kesimpulannya harus dikaitkan dengan judul dan tujuan penelitian. Jangan membuat pernyataan yang tidak didukung secara memadai oleh temuan Anda. Tuliskan perbaikan yang dilakukan pada bidang teknik industri atau sains secara umum. Jangan membuat diskusi lebih lanjut, ulangi abstrak, atau hanya daftar hasil hasil penelitian. Jangan gunakan poin bullet, gunakan kalimat paragraf sebagai gantinya.

Tabel 4.1 Hasil Perhitungan Rasio Keuangan

\begin{tabular}{|c|c|c|c|c|c|c|c|c|}
\hline \multirow{3}{*}{ Tahun } & \multirow{3}{*}{$\begin{array}{l}\text { Nama } \\
\text { Emiten }\end{array}$} & \multicolumn{7}{|c|}{ Rasio } \\
\hline & & \multicolumn{2}{|c|}{ Likuiditas(\%) } & \multicolumn{2}{|c|}{ Solvabilitas(\%) } & \multicolumn{3}{|c|}{ Profitabilitas(\%) } \\
\hline & & $\mathbf{R L}$ & RC & DER & DAR & ROA & ROE & NPM \\
\hline \multirow[t]{4}{*}{2016} & LPKR & 545,4 & 205,1 & 115,6 & 55,9 & 2,69 & 5,55 & 11,19 \\
\hline & PPRO & 119 & 128 & 195,8 & 66 & 4,13 & 12,23 & 7,02 \\
\hline & BKSL & 141,08 & 64 & 58,6 & 36,9 & 4,95 & 7,85 & 27,9 \\
\hline & DMAS & 939,2 & 337,3 & 5,6 & 5,3 & 9,7 & 10,25 & 47,53 \\
\hline
\end{tabular}




\begin{tabular}{|l|l|r|r|r|r|r|r|r|}
\hline \multirow{2}{*}{2017} & PWON & 132,6 & 71 & 87,6 & 46,6 & 8,6 & 16,15 & 36,77 \\
\cline { 2 - 9 } & LPKR & 416,9 & 95,4 & 110,4 & 52,4 & 1,67 & 3,51 & 8,12 \\
\cline { 2 - 9 } & PPRO & 209,3 & 162,9 & 151,1 & 60,1 & 3,65 & 9,19 & 16,96 \\
\cline { 2 - 9 } & BKSL & 155,6 & 83,25 & 50,63 & 33,6 & 3,128 & 4,71 & 28,86 \\
\cline { 2 - 9 } & DMAS & 807,8 & 213,5 & 6,63 & 6,22 & 8,92 & 9,37 & 49,91 \\
\cline { 2 - 9 } & PWON & 171,5 & 171,4 & 82,6 & 45,2 & 8,66 & 15,83 & 35,22 \\
\hline 2018 & LPKR & 402,7 & 93,1 & 98,3 & 49,5 & 3,51 & 6,97 & 13,85 \\
\cline { 2 - 9 } & PPRO & 183,1 & 121,3 & 183,1 & 64,6 & 3,01 & 8,53 & 19,43 \\
\cline { 2 - 9 } & BKSL & 147 & 67 & 53,02 & 34,6 & 2,26 & 3,4 & 27,9 \\
\cline { 2 - 9 } & DMAS & 1276,8 & 318 & 4,33 & 4,15 & 6,61 & 6,9 & 47,9 \\
\cline { 2 - 9 } & PWON & 231,2 & 144,4 & 63,39 & 38,7 & 11,47 & 18,46 & 39,92 \\
\hline \multirow{2}{*}{$\begin{array}{l}\text { Rata- } \\
\text { nata }\end{array}$} & LPKR & 455 & 131,2 & 108,1 & 52,6 & 2,62 & 4,67 & 11,05 \\
\cline { 2 - 9 } & PPRO & 170,46 & 137,4 & 176,66 & 53,56 & 3,59 & 9,98 & 12,8 \\
\cline { 2 - 9 } & BKSL & 147,89 & 71,41 & 54,08 & 35,03 & 3,44 & 5,32 & 28,22 \\
\cline { 2 - 8 } & DMAS & 1007,93 & 289,5 & 5,52 & 5,22 & 8,41 & 8,84 & 48,44 \\
\cline { 2 - 8 } & PWON & 178,43 & 128,93 & 77,86 & 43,5 & 9,57 & 16,81 & 37,30 \\
\hline \multirow{2}{*}{ Standar Industri } & 200 & 100 & 90 & 35 & 30 & 40 & 20 \\
\hline
\end{tabular}

Sumber: Data Diolah Peneliti, 2019

Berdasarkan hasil penelittian dari analisis rasio keuangan, maka dapat dilihat bagaimana kondisi kinerja ke-5 perusahaan properti dan real estate dengan jumlah lembar saham beredar terbanyak pada papan utama yang terdaftar di BEI 2016-2017 dengan membandingkan rata-rata rasio dengan standar rasio adalah sebagai berikut:

\section{Rasio Likuiditas}

Dalam penelitian ini indikator likuiditas yang peneliti gunakan adalah rasio lancar dan rasio cepat.

1. Rasio Lancar

Berdasarkan Tabel 4.1 dapat dilihat bahwa rata-rata rasio lancar LPKR (Lippo Karawaci Tbk) Tahun 2016 sampai dengan Tahun 2018 adalah sebesar 455\%, yang berarti Rp.1 utang lancar perusahaan dijamin oleh Rp. 4,55 aktiva lancar. Kondisi tersebut menyatakan bahwa perusahaan sangat likuid karena rata-rata internal lebih besar dari $200 \%$.

Pertumbuhan rasio lancar LPKR selama kurun waktu 3 tahun dikatakan kurang baik, karena rasio lancar perusahaan berada diatas 200\%. Kondisi ini menunjukkan bahwa perusahaan tidak mengalokasikan aktiva lancar perusahaan secara optimal dan tidak memanfaatkan aktiva lancarnya dengan efisien.

Selanjutnya rata-rata rasio lancar PPRO (PP Properti Tbk) Tahun 2016 sampai dengan Tahun 2018 adalah sebesar 170,46\%, yang berarti Rp.1 utang lancar perusahaan dijamin Rp.1,7 aktiva lancar. Hal tersebut menyatakan bahwa perusahaan cukup likuid karena nilai rata-rata internal berada dibawah rata-rata industri. Pertumbuhan rasio lancar PPRO selama kurun wkatu 3 tahun dikatakan cukup baik, hal tersebut disebabkan kenaikan aktiva lancar 
$\overline{\text { juga diikuti dengan kenaikan utang lancar juga setiap tahunnya. Jadi nilai rata-rata internal }}$ kurang dari $200 \%$ dan mendekati $200 \%$

Rata-rata rasio lancar BKSL (Sentul City Tbk) Tahun 2016 sampai dengan Tahun 2018 adalah sebesar 147,89\%, yang berarti Rp.1 utang lancar perusahaan dijamin oleh Rp. 1,47 aktiva lancar perusahaan, namun terhadap laporan keuangan perusahaan, aktiva lancar tidak mampu menutupi kewajiban lancar perusahaan. Maka perusahaan dinyatakan cukup likuid karena pertumbuhan rasio lancar BKSL selama kurun waktu 3 tahun cukup baik dimana nilai rata-rata internal rasio lancar berada dibawah rata-rata industri dan tidak kurang dari $100 \%$

Rata-rata rasio lancar Puradelta Lestari Tbk (DMAS) Tahun 2016 sampai dengan Tahun 2018 adalah sebesar 1007,93 \% yang berarti Rp.1 utang lancar perusahaan dijamin oleh Rp. 10,07 aktiva lancar. Kondisi tersebut menyatakan bahwa perusahaan sangat likuid karena rata-rata internal lebih besar dari 200\%. Pertumbuhan rasio lancar DMAS selama kurun waktu 3 tahun dikatakan kurang baik, karena rasio lancar perusahaan berada diatas 200\%. Kondisi ini menunjukkan bahwa perusahaan tidak mengalokasikan aktiva lancar perusahaan secara optimal dan tidak memanfaatkan aktiva lancarnya dengan efisien. Dimana nilai aktiva lancar dengan perbandingan 10:1.

Rata-rata rasio lancar Pakuwon Jati Tbk (PWON) Tahun 2016 sampai dengan Tahun 2018 adalah sebesar 178,43 \% yang berarti Rp.1 utang lancar perusahaan dijamin Rp.1,78 aktiva lancar namun terhadap laporan keuangan perusahaan, aktiva lancar tidak mampu menutupi kewajiban lancar perusahaan. Maka perusahaan dinyatakan cukup likuid karena pertumbuhan rasio lancar BKSL selama kurun waktu 3 tahun cukup baik dimana nilai ratarata internal rasio lancar berada dibawah rata-rata industri dan tidak kurang dari $100 \%$.

\section{Rasio Cepat}

Berdasrkan Tabel 4.1 mengenai rasio keuangan LPKR yang menunjukkan rata-rata rasio cepat Tahun 2016 sampai dengan Tahun 2018 sebesar 131,2 \%. Hal tersebut menunjukkan bahwa kewajiban lancar perusahaan sebesar Rp.1 dijamin dengan Rp.1,31 aktiva lancar selain persediaan. Pertumbuhan rasio cepat LPKR selama kurun waktu tiga tahun baik dikarenakan nilai rata-rata rasio cepat berada diatas rata-rata industri atau perbandingan 1:1,31. Kondisi ini menunjukkan bahwa perusahaan tidak harus menjual persediaan bila hendak melunasi utang lancar, tetapi hanya cukup menjual surat berharga dan lain-lainnya.

Rasio keuangan PPRO Tahun 2016 sampai dengan Tahun 2018 dengan rata-rata rasio cepat sebesar $137,4 \%$. Hal tersebut menunjukkan bahwa kewajiban lancar perusahaan sebesar Rp.1 dijamin dengan Rp.1,37 aktiva lancar selain persediaan. Pertumbuhan rasio cepat PPRO selama kurun waktu lima tahun baik dikarenakan nilai rata-rata rasio cepat berada diatas rata-rata industri atau perbandingan 1:1,37. Kondisi ini menunjukkan bahwa perusahaan tidak harus menjula persediaan bila hendak melunasi utang lancar, tetapi hanya cukup menjual surat berharga dan lain-lainnya.

Rasio keuangan BKSL Tahun 2016 sampai dengan Tahun 2018 dengn rata-rata rasio cepat sebesar 71,41\%. Hal tersebut menunjukkan bahwa kewajiban lancar perusahaan Rp.1 dijamin dengan Rp. 0,71 aktiva lancar selain persediaan. Pertumbuhan rasio cepat LPKR selama kurun waktu tiga tahun kurang baik dikarenakan nilai rata-rata rasio cepat berada dibawah rata-rata industri atau perbandingan 1:0,71. Hal ini disebabkan masih rendahnya aktiva lancar selain persediaan perusahaan terhadap kemampuan untuk mengembalikan utang lancar dan perusahaan dinyatakan tidak likuid. Kondisi ini menunjukkan bahwa perusahaan harus menjual persediaan bila hendak melunasi utang lancar.

Rasio keuangan DMAS Tahun 2016 sampai dengan tahun 2018 dengan rata-rata rasio cepat sebesar 289,5\%. Hal tersebut menunjukkan bahwa kewajiban lancar perusahaan sebesar Rp.1 dijamin dengan Rp.2,89 aktiva lancar selain persediaan. Pertumbuhan rasio 
cepat PWON selama kurun waktu tiga tahun kurang baik dikarenakan nilai rata-rata rasio cepat berada diatas rata-rata industri atau perbandingan 1:2,89 hal ini menunjukkan bahwa aktiva lancar selain persediaan tidak dialokasikan secara efisien dan penggunaannya tidak produktif sehingga perusahaan tidak harus menjual persediaan bila hendak melunasi utang lancar tetapi cukup menggunakan kas perusahaan.

Rasio keuangan PWON yang menunjukkan rata-rata rasio cepat Tahun 2016 sampai dengan Tahun 2018 sebesar 128,93\%. Hal tersebut menunjukkan bahwa kewajiban lancar perusahaan sebesar Rp.1 dijamin dengan Rp.1,28 aktiva lancar selain persediaan. Pertumbuhan rasio cepat PWON selama kurun waktu tiga tahun baik dikarenakan nilai ratarata rasio cepat berada diatas rata-rata industri atau perbandingan 1:1,28 sehingga hal ini menunjukkan bahwa perusahaan tidak harus menjual persediaan bila hendak melunasi utang lancar, tetapi hanya cukup menjual surat berharga dan lain-lainnya.

\section{Rasio Solvabilitas}

1. DER

Berdasarkan Tabel 4.1 menunjukkan bahwa rasio keuangan LPKR Tahun 2016 sampai dengan Tahun 2018 dengan rata-rata DER sebesar 108,1 \%. Hal ini berarti menunjukkan bahwa pemberi pinjaman menyediakan sebesar 108,1 \% untuk setiap rupiah yang disediakan pemegang saham. Artinya setiap Rp.1 ekuitas dapat menutupi Rp 1,08 utang. Pertumbuhan rasio DER selam kurun waktu 3 tahun dinyatakan kurang baik sebab nilai rata-rata internal berada diatas rata-rata industri selain itu juga dalam laporan keuangan yang disajikan oleh perusahaan terlihat bahwa modal yang dimiliki perusahaan lebih kecil dibandingkan dengan dengan total utang yang dimiliki perusahaan.

Rasio keuangan PPRO Tahun 2016 sampai dengan Tahun 2018 dengan rata-rata rasio DER sebesar $176,66 \%$ dan nilai rata-rata ini berada diatas rata-rata industri. Hal ini berarti menunjukkan bahwa pemberi pinjaman menyediakan sebesar 176,66 \% untuk setiap rupiah yang disediakan pemegang saham. Artinya setiap Rp.1 ekuitas dapat menutupi Rp 1,76 utang. Pertumbuhan rasio DER selam kurun waktu 3 tahun dikatakan kurang baik, karena dalam laporan keuangan yang disajikan oleh perusahaan terlihat bahwa modal yang dimiliki perusahaan lebih kecil dibandingkan dengan dengan total utang yang dimiliki perusahaan.

Rasio keuangan BKSL Tahun 2016 sampai dengan Tahun 2018 menunjukkan rata-rata DER sebesar 54,08 \%. Hal ini berarti menunjukkan bahwa pemberi pinjaman menyediakan sebesar 54,08 \% untuk setiap rupiah yang disediakan pemegang saham. Artinya setiap Rp.1 ekuitas dapat menutupi Rp 0,54 utang. Pertumbuhan rasio DER selam kurun waktu 3 tahun dikatakan baik, karena dalam laporan keuangan yang disajikan oleh perusahaan terlihat bahwa modal yang dimiliki perusahaan lebih besar dibandingkan dengan dengan total utang yang dimiliki perusahaan.

Rasio keuangan DMAS Tahun 2016 sampai dengan Tahun 2018 dengan rata-rata DER sebesar 5,52\% .Hal ini berarti menunjukkan bahwa pemberi pinjaman menyediakan sebesar $5,52 \%$ untuk setiap rupiah yang disediakan pemegang saham. Artinya setiap Rp.1 ekuitas dapat menutupi Rp 0,055 utang. Pertumbuhan rasio DER selam kurun waktu 3 tahun dikatakan baik, karena dalam laporan keuangan yang disajikan oleh perusahaan terlihat bahwa modal yang dimiliki perusahaan lebih besar dibandingkan dengan dengan total utang yang dimiliki perusahaan.

Rasio keuangan PWON Tahun 2016 sampai dengan Tahun 2018 dengan rata-rata rasio DER sebesar 77,86 \%. Hal ini berarti menunjukkan bahwa pemberi pinjaman menyediakan sebesar 77,86 \% untuk setiap rupiah yang disediakan pemegang saham. Artinya setiap Rp.1 ekuitas dapat menutupi Rp 0,77 utang. Pertumbuhan rasio DER selam kurun waktu 3 tahun dinyatakan baik sebab nilai rata-rata internal berada dibawah rata-rata industri selain itu juga dalam laporan keuangan yang disajikan oleh perusahaan terlihat bahwa modal yang dimiliki perusahaan lebih besar dibandingkan dengan dengan total utang yang dimiliki perusahaan. 
2. DAR

Berdasarkan Tabel 4.1 menejelaskan mengenai rasio keuangan LPKR Tahun 2016 sampai dengan Tahun 2018 dengan rata-rata rasio DAR sebesar 52,6\% atau berbanding 52,6:1. Hal tersebut berarti setiap Rp.1 total aktiva dapat menutupi Rp 0,52 hutang. Pertumbuhan rasio DAR selama kurun waktu 3 tahun adalah kurang baik karena nilai ratarata DAR berada diatas rata-rata industri dimana semakin tinggi rasio ini maka semakin tinggi pula tingkat resiko keuangan dari perusahaan. Jumlah Total aktiva yang ada di laporan keuangan perusahaan tidak dapat menutupi utang-utang perusahaan.

Rata-rata rasio DAR PPRO Tahun 2016 sampai dengan Tahun 2018 yang yaitu sebesar $53,56 \%$. Hal tersebut berarti setiap Rp.1 total aktiva dapat menutupi Rp 0,53 hutang. Pertumbuhan rasio DAR selama kurun waktu 3 tahun adalah kurang baik karena nilai ratarata DAR berada diatas rata-rata industri dimana semakin tinggi rasio ini maka semakin tinggi pula tingkat resiko keuangan dari perusahaan dan sebaliknya makin rendah rasio ini maka semakin rendah tingkat resiko perusahaan.

Rata-rata rasio DAR BKSL Tahun 2016 sampai dengan Tahun 2018 adalah sebesar 35,03\%. Hal tersebut berarti setiap Rp.1 total aktiva dapat menutupi Rp 0,35 hutang. Pertumbuhan rasio DAR selama kurun waktu 3 tahun adalah baik karena nilai rata-rata DAR sama denagan rata-rata industri dimana dari laporan keuangan perusahaan menunjukkan bawa nilai aktiva perusahaan lebih besar dibandingkan utang perusahaan. Semakin tinggi rasio ini maka semakin tinggi pula tingkat resiko keuangan dari perusahaan dan sebaliknya makin rendah rasio ini maka semakin rendah tingkat resiko perusahaan.

Rata-rata nilai rasio DAR DMAS Tahun 2016 sampai dengan Tahun 2018 adalah sebesar 5,2\%. Hal tersebut berarti setiap Rp.1 total aktiva dapat menutupi Rp 0,052 hutang. Pertumbuhan rasio DAR selama kurun waktu 3 tahun adalah baik karena nilai rata-rata DAR dibawah rata-rata industri dimana semakin tinggi rasio ini maka semakin tinggi pula tingkat resiko keuangan dari perusahaan dan sebaliknya makin rendah rasio ini maka semakin rendah tingkat resiko perusahaan.

Rasio keuangan PWON Tahun 2016 sampai dengan Tahun 2018 dengan rata-rata rasio DAR sebesar 43,5\% atau berbanding 43,5:1. Hal tersebut berarti setiap Rp.1 total aktiva dapat menutupi Rp 0,43 hutang. Pertumbuhan rasio DAR selama kurun waktu 3 tahun adalah kurang baik karena nilai rata-rata DAR berada diatas rata-rata industri dimana semakin tinggi rasio ini maka semakin tinggi pula tingkat resiko keuangan dari perusahaan. Jumlah Total aktiva yang ada di laporan keuangan perusahaan tidak dapat menutupi utang-utang perusahaan.

\section{Rasio Profitabilitas}

1. ROA

Rata-rata internal ROA dari 5 sampel perusahaan properti dan real estate yang terdaftar di BEI adalah LPKR (2,62\%), PPRO (3,59\%), BKSL (3,44\%), DMAS( 8,41\%) dan PWON (9,57\%). Artinya setiap Rp 1 aktiva yang ditanamkan mampu menghasilkan laba sebesar Rp. 0,0262 (LPKR), Rp.0,0359( PPRO), Rp. 0,0344 (BKSL), Rp.0,0841 (DMAS) dan Rp. 0,0957( PWON). Pertumbuhan ROA masing-masing perusahaan belum dikatakan baik karena berada dibawah rata-rata industri sehingga perusahaan belum dikatakan profitabilitas dalam menghasilkan keuntungan dari total aktiva yang dimiliki. Dalam pencapaian keuntungan yang didapat dari total aktiva maka perusahaan harus lebih meningkatkan pendapatan agar laba yang didapat akan lebih besar sehingga dapat mencapai dari standar rasio yang ditentukan.

2. ROE

Rata-rata internal ROE dari 5 sampel perusahaan properti dan real estate yang terdaftar di BEI adalah LPKR (4,67\%), PPRO (9,98\%), BKSL (5,32\%), DMAS $(8,84 \%)$ dan PWON $(16,81 \%)$. Artinya setiap Rp 1 aktiva yang ditanamkan mampu menghasilkan laba sebesar 
Rp. 0,0467 (LPKR), Rp.0,0998( PPRO), Rp. 0,0532 (BKSL), Rp.0,0884 (DMAS) dan Rp. 0,1681 ( PWON). Pertumbuhan ROE masing-masing perusahaan belum dikatakan baik karena berada dibawah rata-rata industri sehingga perusahaan belum dikatakan profitabilitas dalam menghasilkan keuntungan dari ekuitas yang dimiliki. Dalam pencapaian keuntungan yang didapat dari ekuitas maka perusahaan harus lebih meningkatkan pendapatan agar laba yang didapat akan lebih besar serta lebih memperhatikan hutanghutang perusahaan sehingga dapat mencapai laba yang maksimal

\section{NPM}

Rata-rata internal NPM dari 5 sampel perusahaan properti dan real estate yang terdaftar di BEI adalah LPKR (11,05\%), PPRO (17,80\%), BKSL $(28,22 \%)$, DMAS $(48,44 \%)$ dan PWON (37,30\%). Artinya setiap Rp 1 modal sendiri yang ditanamkan mampu menghasilkan laba sebesar Rp. 0,1105 (LPKR), Rp.0,1780 (PPRO), Rp. 0,2822 (BKSL), Rp.0,4844 (DMAS) dan Rp. 0,373 ( PWON). Pertumbuhan NPM perusahaan BKSL,DMAS dan PWON dikatakan baik karena rata-rata internal berada diatas rata-rata industri sehingga perusahaan dikatakan profitabilitas dalam menghasilkan keuntungan dari aktivitas perusahaan yang dijalankan. Sedangakan perutumbuhan NPM perusahaan LPKR dan PPRO belum baik karena rata-rata internal berada dibawah rata-rata industri.

\section{KESIMPULAN DAN SARAN \\ Kesimpulan} berikut:

Berdasarkan hasil penelitian dan pembahasan maka dapat diambil kesimpulan sebagai

1. Kinerja keuangan perusahaan properti dan real estate ditinjau dari likuiditas yang diukur melalui rasio lancar dan rasio cepat Tahun 2016 sampai dengan Tahun 2018 dengan perusahaan yang memiliki rasio likuditas baik karena perusahaan mampu untuk menutupi kewajiban lancar yang dimiliki perusahaan adalah Pakuwon Jati (PWON), Lippo Karawaci Tbk (LPKR) dan PP Properti (PPRO), sedangkan perusahaan dengan rasio likuditas kurang baik adalah Puradelta Lestari (DMAS) dan Sentul City (BKSL).

2. Kinerja keuangan perusahaan properti dan real estate ditinjau dari solvabilitas yang diukur melalui rasio DER dan DAR Tahun 2016 sampai dengan Tahun 2018 dengan perusahaan yang memiliki rasio solvabilitas baik karena perusahaan mampu untuk menutupi utang-utang yang dimiliki perusahaan dari pihak luar yang berasal dari aktiva dan modal perusahaan adalah Puradelta Lestari (DMAS) dan Sentul City (BKSL), sedangkan perusahaan dengan rasio solvabilitas kurang baik adalah Pakuwon Jati (PWON), PP Properti (PPRO) dan Lippo Karawaci Tbk (LPKR)

3. Kinerja keuangan perusahaan properti dan real estate ditinjau dari profitabilitas yang diukur melalui rasio ROA, ROE dan NPM Tahun 2016 sampai dengan Tahun 2018 dengan perusahaan yang memiliki rasio profitabilitas baik karena perusahaan mampu mendapatkan profit yang besar yang diperoleh dari pengelolaan aktiva dan ekuitas yang dimiliki perusahaan adalah Puradelta Lestari (DMAS) dan Pakuwon Jati (PWON), sedangkan perusahaan dengan rasio profitabiltas kurang baik Lippo Karawaci Tbk (LPKR) dan PP Properti (PPRO dan Sentul City (BKSL).

\section{Saran}

Berdasarkan hasil penelitian maka saran yang dapat diajukan bagi perusahaan adalah para manajer perusahaan harus lebih meningkatkan lagi kinerja perusahaan sehingga profit yang dihasilkan dapat lebih maksimal sehingga dapat menarik investor untuk berinvestasi, sedangkan bagi peneliti selanjutnya dapat menggunakan variabel dan sektor perusahaan yang lebih luas lagi dalam penelitian yang akan dilakukan. 


\section{DAFTAR RUJUKAN}

Fahmi, Irham. 2016. Pengantar Manajemen Keuangan.Penerbit Alfabet, Bandung.

Febrianty dan Wulandari. 2017. Kinerja Keuangan Perusahaan Property dan Reaal Estate di BEI selamaPeriode 2012- 2016 yang termasuk di Indeks LQ45 (Studi pada Perusahaan yang Termasuk Pemeringkatan Indeks LQ45 Periode Februari 2017-Juli 2017). Jurnal Manajemen dan Bisnis Surabaya Vol.15 (1)

Hamdany,Debby. 2018. Analisis Kinerja Keuangan Perusahaan Properti dan Real Estate yang terdaftar di BEI Tahun 2014-2016. Jurnal Administrasi Bisnis Vol.6 No.1

Hasanah, Ilmiatul., Susyanti., Jeni.,dan Wahono,Budi. 2017.Analisis Kinerja Perusahaan Real Estate dan Property yang Terdaftar di Bursa Efek Indonesia sebelum dan Selama Pemerintahan Jokowi.Jurnal Warta Ekonomi. Vol 07. No.17.

http:/m.cnnindonesia.com

Husnan, Suad, dan Pujiastuti. 2007. Manajemen Keuangan, Edisi Kelima. UPP AMP YKPN, Yogyakarta

Idx.co.id

Kasmir. 2014. Analisis Laporan Keuangan edisi Ke 1 cetakan ke Tujuh. PT Raja Grafindo Persad, Jakarta

Kasmir. 2016. Analisis Laporan Keuangan. PT Raja Grafindo Persad, Jakarta

Munawir. 2010. Analisa Laporan Keuangan. Liberty, Yogyakarta

Nafilah, Firqatun., Moh.Amin., dan M. Cholid Mawardi. 2019. Analisis Kinerja Keuangan Perusahaan Real Estate dan Property yang Terdadtar di Otoritas Jasa Keuangan Sebelum dan Selama Pemerintahan Presiden Jokowi. E-JRA Vo.08 No.04

Prima, Ghaniy Prima., Hermanto Siregar., dan Fery Syarifuddin. 2019. Analisis Kinerja Keuangan Perusahaan Properti yang Terdaftar di BEI Sebelum dan Sesudah Kebijakan Loan To Value. Jurnal Riset Manajemen dan Bisnis Fakultas Ekonomi UNIAT Vol.4 No.1

Undang- Undang Dasar Negara Republik Indonesia Tahun 